\title{
PROGRESS AT OKLAHOMA STATE PENITENTIARY
}

\author{
Gilbert Geis \\ Department of Sociology, UNIVERSITY OF OKLAHOMA
}

\begin{abstract}
A GUARD, with twenty-four years of service at the Oklahoma State Penitentiary, McAlester, made his appraisal of recent trends at the prison in these terms:
\end{abstract}

"Years ago," he drawled, "we used to beat the hell out of the men. Now we treat them better, never hit them except in self-defense." The guard explained past inmate disorders in the prison with the same frame of reference: "Hell, even a dog will bite back if you kick it often enough.

"Things are changing in prisons," he continued. "Here, too. And there's been more changes in the past few years than all the previous time put together."

The Penitentiary is, as the guard noted, in a state of transition, and recent changes are very encouraging to an outside observer, though many doubts remain as to the validity of the basic rehabilitative orientation, and as to the overall outlook for more than stopgap financing and hole-plugging.

Key figure at McAlester is Jerome J. Waters, Jr., appointed Warden in June, 1951, after 34 years of army service, including a stint as professor of military science at the University of Oklahoma. Waters' penal philosophy appears to have its roots in his military background, and he has done much to organize and systematize a situation that was rather chaotic before his term began. Recent changes, such as the following, for instance, represent solid achievements: Raising of the basal salary of new personnel from $\$ 160$ to $\$ 200$ a month; modernization of the physical plant, including the reconstruction of the now air-conditioned chapel; expansion of the classification and vocational program; streamlining of the food setup, with the raising and growing of many more items at the prison ("Feed an army to fight," says the Warden. "Don't feed inmates and they fight."); intelligence testing of new personnel; and a thorough going table of organization for the divisions of the prison, plus many other minor, but valuable, changes.

Epitomizing the tighter coordination of affairs at the prison is an 80-page custodial manual, prepared by Waters, which outlines the duties of every position in the prison, detailing specific responsibilities, and noting many conduct rules. New employees thus find their job roles completely structured, rather than having to flounder along uncharted paths. General rules listed in the manual for all custodial personnel, for instance, include: 
"Don't question a man's religious beliefs."

"Don't hold a grudge against a man." man."

"Don't pry into the nature of the crime committed by the

These are some of the landmarks of Waters' 21/2-year regime. The Warden is a firm believer in a maxim that he often quotes: "Idle hands make mischief," and he apparently is stressing, above all other rehabilitative approaches, the expansion of a vocationallyoriented work program for inmates. Critics, agreeing wholeheartedly with his efforts to improve the work setup, nonetheless suspect that this phase is being over-emphasized at the expense of other items, particularly extensive psychiatric and counseling ventures. The Penitentiary has one trained psychologist who has time only for routine testing tasks.

Two other recent innovations are the establishment of an Alcoholics Anonymous branch at the prison under the guidance of Dwight Sills, a classification officer, and the granting of four days good time to every inmate possessing a clean prison record who donates a pint of blood to the blood bank. A prisoner is allowed to make one donation every three months.

Meanwhile, personnel morale, though probably at an all-time peak, still quivers with perennial political qualms.

"Guess wrong in politics and you may be looking for a new job," one employee noted cynically. Then: "A man should be able to vote as a citizen, not as a ward of the machine."

Waters has tightroped his way through the ticklish patronage problem, refusing to appoint persons who fail to meet his established (and ever-increasing) minimum intelligence requirements, though preferring men recommended by legislators. It is interesting that the first I.Q. testing of prospective employees showed them scoring 86.55. Simultaneously, the inmate population tested out at 87.47.

Oklahoma, commentators agree, needs a non-political, continuing supervisory board with exclusive jurisdiction over the prison system, plus a solid tenure setup for hired penal personnel.

In addition, there remains a desperate need for a minimum security institution, preferably in the central portion of the State. The 42-year-old McAlester plant has 1,980 inmates, which is too many for its facilities. Classification is meaningless if the inmate has no outlet for his particular talents, and must spend his days in idleness. Also, there is too much crowding into twoand four-man cells. Oklahoma, in addition, very much needs a comprehensive probation system: 51 percent of the men received 
at McAlester last year were first offenders, and 41 percent of all inmates coming to McAlester have sentences of two years or less.

Yet, in all, rehabilitative knowledge and interest is prevalent and widespread among the top prison men at McAlester, though the age-old battle between the economy-minded legislature and the prison leaders, who attempt to point out that appropriation economy aimed at the prison is, in the end, a false economy, is always in the foreground, severely limiting any long-range planning attempts.

On other fronts, the Legislature did adopt a new mental health program calling for a period of observation in the State mental hospital when the question of sanity is raised in criminal proceedings, though county attorneys have complained that this law is being used indiscriminately to postpone the trying of "hot" cases. Then, late in January, the State convention of sheriffs and peace officers passed a resolution calling for the construction of a mental hospital for the criminally insane inside the walls of the McAlester penitentiary, declaring that the present methods of treating such prisoners were "inadequate."

In addition, Governor Johnston Murray recently made a proposal that should attract wide support. Speaking at the Southern Governors' Conference, Murray called upon neighboring states to join with Oklahoma in setting up an inter-state hospital devoted exclusively to the treatment of sex offenders. Whether this proposal will take root is debatable, but it represents some of the sound thought that is ever-increasingly being brought to bear on penal problems in Oklahoma. 